\title{
Pollution of mercury and cyanide soils and plants in surrounding in the Artisanal and Small-Scale Gold Mining (ASGM) at Sekotong District, West Lombok, West Nusa Tenggara
}

Suhadi ${ }^{1}$, Sueb ${ }^{2,}$, B. K. Muliya ${ }^{3}$, Anisa Meilia Ashoffi ${ }^{4,}$ *

Department of Biology, Universitas Negeri Malang, Malang, Indonesia

11 suhadi@um.ac.id; ${ }^{2}$ sueb@um.ac.id; ${ }^{3}$ khandra.1703418@students.um.ac.id;

4 anisaashoffi10@gmail.com*

* Corresponding author

\begin{tabular}{|c|c|}
\hline ARTICLE INFO & ABSTRACT \\
\hline \multirow[t]{2}{*}{$\begin{array}{l}\text { Article history } \\
\text { Submission May 15, } 2021 \\
\text { Revision May 28, } 2021 \\
\text { Accepted June 10, } 2021 \\
\text { Keyword } \\
\text { Artisanal and small-scale } \\
\text { gold mining } \\
\text { Cyanide } \\
\text { Pollution of mercury }\end{array}$} & $\begin{array}{l}\text { The Artisanal and small-scale gold mining (ASGM) activities } \\
\text { at Sekotong District, NTB have a negative impact on the } \\
\text { environment. This study aims to determine the content of } \\
\text { mercury and cyanide in soil and plants around gold mining. } \\
\text { The research method used is descriptive explorative. The } \\
\text { research sample was taken purposively at } 4 \text { locations and } \\
\text { sample analysis at the Chemical Laboratory of Universitas } \\
\text { Brawijaya. The results showed that the Hg and HCN content } \\
\text { in surface soil ranged from } 2.90-26.94 \text { and } 63.93-104.08 \\
\text { mg/Kg, Hg and HCN in soil with a depth of } 30 \mathrm{~cm} \text { ranging } \\
\text { from 3.48-53.86 and } 66.59-106.55 \mathrm{mg} / \mathrm{Kg} \text {. The Hg and HCN } \\
\text { content in plants ranges from } 1.23-8.15 \text { and } 18.41-52.85 \\
\text { mg/Kg. Referring to the standards set by WHO and the rules } \\
\text { of Health the Republic Indonesia } 2016 \text {, soil and plants have } \\
\text { polluted and have a negative impact on other living things. }\end{array}$ \\
\hline & This is an open-access article under the CC-BY-SA license \\
\hline
\end{tabular}

Conflict of interest: The authors declare that they have no conflicts of interest.

\section{Introduction}

Based on a survey by the International Labour Organization (ILO) and Mining, Minerals, and Sustainable Development (MMSD) ${ }^{1}$, an estimated 13 million people worldwide from 30 developing countries are directly involved in gold mining. People's gold mining or in a foreign language called Artisanal and Small-Scale Mining (ASGM) accounts for around 50\% of world mining ${ }^{1}$. Indonesia has many mountains and rich in natural resources such as mineral resources. Gold is one of the mineral resources found in Indonesia. Indonesia is known as one of the major gold producers in the world ${ }^{2}$. According to Lamare, there are 90 gold producing countries and Indonesia has ranked 8th in the world with official gold ownership of 73.1 tons $^{3}$.

In Indonesia, community mining is regulated in Mineral and Coal Law (Law No. 4/2009). The Government of Indonesia issued Government Regulation No. 22/2010 concerning Mining Areas. The regulation revealed that mining must obtain community mining areas (WPR). The authority to grant community mining areas in regional government is regulated by the district. In the last 5 years the number of gold mining has doubled. In 2010, there were around 900 hotspots with 250,000 miners, including women and children ${ }^{4}$. Indonesia is one of the main locations for community gold mining activities ${ }^{5}$. One of the people's gold mining locations is located at Sekotong District, West Lombok Regency, West Nusa Tenggara Province. Since 
early 2008 mining activities have been carried out by local people without permission ${ }^{6}$. Ulfa stated that $50 \%$ of 42,000 Sekotong residents carried out activities related to gold mining and processing ${ }^{7}$.

It is estimated that mercury used in 2011 reached 1.15 tons per day ${ }^{8}$. The process of gold processing begins with crushed gold-filled rock into $1-2 \mathrm{~cm}$ and then processed through the amalgamation process using logs with a length of 55-60 cm and a diameter of $30 \mathrm{~cm}$ with 3-5 iron bars in the spindle as a grinder. Amalgamation gold processing is done by mixing ore with mercury to form amalgam (Au-Hg alloy metal) with water media. Each spindle can accommodate 2-3 kg of gold ore for 3-4 hours. In each amalgamation process about 250-500 grams of $\mathrm{Hg}$ are added to the spindle to a fine grain of less than $0.5 \mathrm{~mm}$. According to the results of observations carried out on 30 July 2018, in addition to mercury some chemicals used in the amalgamation and cyanidation processes such as carbon, potassium, and cyanide.

A small portion of mercury evaporates and spreads into the air, others are discharged into the environment along with tailings, in rivers, the sea, and agricultural land. Mercury is then absorbed by fish and then consumed by humans so that it leads to fatal. It is known that mercury is the most toxic metal that is harmful to human health. In addition, tailings also contain some heavy metals which can be toxic to agricultural crops ${ }^{2}$.

From the results of research on environmental conditions resulting from gold mining at Sekotong experienced high mercury and cyanide contamination. The results of the analysis of the mercury content of the people's gold mining waste in January 2016 showed the mercury content in the waste collection basin of 4.04-29.88 $\mathrm{ppm}^{7}$. The results of another study showed that the mercury content in the soil varied from 25 to $40 \mathrm{ppm}^{2}$. The mercury content in rice, corn and rice grown on tailings disposal is around $0.20 \mathrm{ppm}$. The results of other studies explained the average mercury content at Sekotong Barat Lombok gold mine reached 8363.64 $\mathrm{ppm}^{8}$. This figure is much higher than the WHO standard $0.001 \mathrm{ppm}^{9,10}$ or the Indonesian standard 0.005 ppm based regulation of the Minister of Health of the Republic of Indonesia ${ }^{11}$. The purpose of this study was to analyse the content of mercury and cyanide in soils and plants at Sekotong District gold mining.

\section{Method}

This research is an export descriptive study that aims to obtain information related to mercury and cyanide pollution in soils and plants at Sekotong Lombok Barat West Nusa Tenggara community mining area. The research sample was taken in January 2019 and the analysis was carried out at the UB Laboratory of Chemistry by using the Atomic Absorption Spectrophotometry (AAS) and Argentometry methods. Samples were taken at 4 locations, the soil and plant sampling points in the following Table 1.

Table 1. The soil and plant sampling points

\begin{tabular}{|c|c|c|c|c|}
\hline \multirow{2}{*}{ Location } & \multirow{2}{*}{ Village } & \multirow{2}{*}{ Sample Point } & \multicolumn{2}{|c|}{ Coordinate } \\
\hline & & & Latitude & Longitude \\
\hline \multirow[t]{2}{*}{ Sekotong Central } & Telaga Lebur & 1 & S 0847.101' & E $116^{\circ} 02.423^{\prime}$ \\
\hline & & 2 & S $08^{\circ} 47.081^{\prime}$ & E $116^{\circ} 02.423^{\prime}$ \\
\hline \multirow[t]{2}{*}{ Sekotong West } & Lendang Re I & 1 & S $08^{\circ} 45.671^{\prime}$ & E $116^{\circ} 02.262^{\prime}$ \\
\hline & & 2 & S $08^{\circ} 45.672^{\prime}$ & E $116^{\circ} 02.266^{\prime}$ \\
\hline \multirow[t]{2}{*}{ Pelangan } & Tembowong 1 & 1 & S $08^{\circ} 45.623^{\prime}$ & E $116^{\circ} 02.279^{\prime}$ \\
\hline & & 2 & S $08^{\circ} 45.617^{\prime}$ & E $116^{\circ} 02.286^{\prime}$ \\
\hline \multirow[t]{2}{*}{ Pelangan } & Tembowong 2 & 1 & S $08^{\circ} 48.606^{\prime}$ & E $115^{\circ} 56.484^{\prime}$ \\
\hline & & 2 & S 0848.594' & E $115^{\circ} 56.488^{\prime}$ \\
\hline
\end{tabular}

How to take soil and plant samples by purposive sampling with stratified random so that the quality of the sample is more representative. Sampling based on; (1) determine the centre 
of the location of the land affected by pollutants, (2) the land is divided into 2 division line, (3) draw a perpendicular line in the middle of the division line, (4) choose a sampling location in each quadrant, (5) each quadrant area of sampling with various depths, (6) depth of 0-30 cm to determine the quality of topsoil or area of plant root activity while $30-100 \mathrm{~cm}$ to find out chemicals in the soil due to leakage/spillage of a waste, (7) samples soil and plants are put on plastic samples and given information using label paper ${ }^{12}$.

Data analysis was performed by comparing the maximum concentrations of mercury and cyanide in soils and plants. Based on the Regulation of the Minister of Health of the Republic of Indonesia Number 57 Year 2016, the threshold level of mercury allowed on the ground is $0.005 \mathrm{mg} / \mathrm{L}$ and plants are $0.001 \mathrm{mg} / \mathrm{L}$. Whereas the standard threshold for plant cyanide is 0.5 $\mathrm{mg} / \mathrm{L}$ and in soils $0.8 \mathrm{mg} / \mathrm{L}$ according to $\mathrm{WHO}^{10}$.

\section{Results and Discussion}

The results of the analysis of mercury and cyanide content in soil and plants in Tables 2 and 3 are as follows.

Table 2. Results of analysis of mercury and cyanide content in soil

\begin{tabular}{lcc}
\hline \multirow{2}{*}{ Land Code } & $\begin{array}{c}\mathbf{H g} \pm \mathbf{S D} \\
\mathbf{~} \mathbf{m g} / \mathbf{K g}\end{array}$ & $\begin{array}{c}\mathbf{H C N} \pm \mathbf{S D} \\
\mathbf{m g} / \mathbf{K g}\end{array}$ \\
\hline ST P & $26.94 \pm 0.18$ & $95.60 \pm 0.50$ \\
ST K & $3.48 \pm 0.18$ & $106.55 \pm 0.58$ \\
P1 P & $7.98 \pm 0.16$ & $63.93 \pm 0.01$ \\
P2 P & $7.89 \pm 0.12$ & $104.08 \pm 0.08$ \\
P1 K & $42.32 \pm 0.34$ & $89.67 \pm 0.01$ \\
P2 K & $8.65 \pm 0.1$ & $66.59 \pm 0.01$ \\
SB P & $2.90 \pm 0.00$ & $98.50 \pm 0.02$ \\
SB K & $53.86 \pm 0.31$ & $104.92 \pm 0.08$ \\
\hline
\end{tabular}

Description information of the land code: Sekotong Tengah Surface (ST P), Sekotong Tengah Depth $30 \mathrm{~cm}$ (ST K), Pelangan 1 Surface (PI P), Pelangan 1 Depth $30 \mathrm{~cm}$ (P1 K), Pelangan 2 Surface (P2 P), Pelangan 2 Depth $30 \mathrm{~cm}$ (P2 K), Sekotong Barat Surface (SB P), and Sekotong Barat Depth $30 \mathrm{~cm}$ (SB K).

Table 3. Results of Analysis of Cyanide and Mercury Content in Plants

\begin{tabular}{lcc}
\hline \multicolumn{1}{c}{ Plant } & $\begin{array}{c}\mathbf{H g} \pm \mathbf{S D} \\
\mathbf{~ m g / K g}\end{array}$ & $\begin{array}{c}\text { HCN } \pm \mathbf{S D} \\
\mathbf{~ m g} / \mathbf{K g}\end{array}$ \\
\hline Eleusine indica L & 0 & 45.50 \\
Musa paradisiaca L & 0 & 37.24 \\
Manihot esculenta C & $1.83 \pm 0.00$ & 52.85 \\
Sesbania grandiflora L & $3.82 \pm 0.00$ & 31.15 \\
Capsicum sp L & $8.15 \pm 0.20$ & 40.39 \\
Rhizophora apiculate L & $3.07 \pm 0.00$ & 46.52 \\
Mangifera indica L & $1.86 \pm 0.00$ & 24.61 \\
Oryza sativa L & $1.23 \pm 0.00$ & 18.41 \\
\hline
\end{tabular}

\section{Analysis of Mercury and Cyanide Pollution in Soil}

The results of the analysis of the mercury and cyanide contents, which are listed in Table 2 , stated that the land in the people's gold mining area of the Sekotong District of West Lombok is polluted due to the levels of pollutants of mercury and cyanide. In soil samples exceeding the WHO standard threshold which is $0.001 \mathrm{ppm}$ or the Indonesian standard $0.005 \mathrm{ppm}$ (Regulation 
of the Minister of Health of the Republic of Indonesia) ${ }^{11}$ for mercury and cyanide threshold in the soil $0.8 \mathrm{mg} / \mathrm{l}$ according to $\mathrm{WHO}^{10}$.

Land is a place of life for various living things, including for plants to grow, to store and purify water, and to maintain the earth's atmosphere. The existence of gold mining activities adjacent to agricultural areas such as at Sekotong has the potential to reduce the quality of land, especially paddy land, because mining waste is accommodated in paddy fields or discharged into rivers/water bodies, while the river is a source of irrigation water for paddy fields in these areas, especially in the dry season. Waste processing tailings from the separation of gold ore (amalgamation) which are dumped on agricultural land, so that the land becomes polluted and unproductive $^{13}$.Waste that comes out of the engine was detected to contain up to $62.27 \mathrm{ppm} \mathrm{Hg}$ in the liquid and $598.14 \mathrm{ppm} \mathrm{Hg}$ in the sediment. Inevitably, several rivers and rice fields around the area were also affected ${ }^{14}$. Pollution of heavy metals in paddy soils is suspected to be accumulated into plants. If the plant parts are consumed by animals or humans, it will gradually cause health problems for those who consume them ${ }^{15}$.

The concentration of mercury $(\mathrm{Hg})$ in harmless soil is $0.005 \mathrm{ppm}^{16}$, while Mirdat states that normal conditions in the soil are in the range of $0.01-0.3 \mathrm{ppm}$, while the critical range is 0.3-0 .5 $\mathrm{ppm}^{17}$. The concentration of mercury $(\mathrm{Hg})$ will be greater in the dry season ${ }^{18}$ and usually accumulates $75 \mathrm{~cm}$ above the ground so that it is easily absorbed by plants ${ }^{19}$. Mercury and cyanide content that exceeds the Environmental Quality Standards can cause harm to humans, including brain damage, disability, to death ${ }^{20}$.

Analysis of mercury and cyanide pollution in plants

Analysis of mercury and cyanide content in plants around the gold processing site, leaf samples were taken from 8 plant species, namely rice (Oryza sativa L.), cassava (Manihot esculenta C.), bananas (Musa paradisiaca Linnaeus), chillies (Capsicum sp L .), turi (Sesbania grandiflora L.), mango (Mangifera indica L.), mangrove (Rhizophora apiculate L.), and grass bones (Eleusine indica L.). This plant was chosen based on the distribution of plants that always exist in each research sample collection location, with a view to knowing the effects of mercury and cyanide pollution. The selected plants have the closest distance to the location of the gold processing activity.

From the results of the analysis of the mercury and cyanide content listed in Table 3, it was stated that some plants in the people's gold mining area Sekotong Lombok Barat District were contaminated with mercury and cyanide waste in plants exceeding the standard threshold determined by the Health of the Republic of Indonesia Number 57 of 2016, the threshold level mercury in plants $0.001 \mathrm{mg} / \mathrm{L}$. Whereas the cyanide threshold standard in plants is $0.5 \mathrm{mg} / \mathrm{L}$ and according to $\mathrm{WHO}^{10}$. This means that plants in the region cannot be consumed by surrounding living things because they contain high pollutants.

Absorption and accumulation of heavy metals by plants can be divided into three processes, (1) metal absorption by roots, (2) metal translocation from roots to other plant parts, and (3) localization of certain metal cells so as not to inhibit metabolism ${ }^{21}$. Mercurycontaminated environments produce different responses in the physiological adaptability of plants. Plants that grow in the PETI area, show a tendency to accumulate Hg and CN in very high levels in the roots ${ }^{22}$.

Cyanide is a strong and fast-acting asphyxia that prevents tissue oxygen utilization by inhibiting the cell's respiratory enzyme, cytochrome oxidase. Inhaling or swallowing cyanide produces a reaction in a few seconds and death within a few minutes ${ }^{23}$. The level of cyanide contamination in the soil when exposed to light will turn into free cyanide which is very toxic and volatile. Compounds containing cyanide ions are poisons that work quickly, which mainly disrupt the process of cellular respiration, which results in a number of diseases, even death ${ }^{24}$. Free cyanide and cyanide complex, including $\mathrm{HCN}$ and $\mathrm{CN}-$ are the most reactive and toxic substances of all industrial pollutants ${ }^{25}$. 
Plants as producers that occupy the first food chain. This means that plants have an important role for the life of other living things. If a plant is declared exposed to heavy metals mercury and cyanide and then consumed by humans and animals, then the heavy metal will accumulate in the human body and the animal and then will have a negative impact on human and animal health. Another problem arising from mining activities is high soil $\mathrm{pH}$, which is 7.9. This figure shows that the soil in the study area is basic. High soil $\mathrm{pH}$ will cause immobilization of the elements so that plants cannot grow properly. High soil $\mathrm{pH}$ also causes changes in plant metabolism which in turn can cause a decrease in crop yields ${ }^{26}$.

Mercury is the most toxic heavy metal to soil biota both animals and plants, but plants can survive in extreme environmental conditions including the content of mercury ${ }^{27}$. Mercury $(\mathrm{Hg})$ can enter the plant through the roots and transported by xylem vessels, then accumulated in all parts of the plant starting from the roots, stems and leaves ${ }^{28}$. The presence of mercury in plants can inhibit germination ${ }^{29,30}$, root lengthening and plant growth ${ }^{31}$. Mercury poisoning (Hg) can inhibit the process of mitosis, reduced cell wall component synthesis and alter photosynthetic activity ${ }^{32}$. The activity of mercury $(\mathrm{Hg})$ in plants is by reducing the elements of manganese, potassium, magnesium, and iron in the roots and root tips so that it interferes with growth ${ }^{30}$, this is because the plant parts which are the gathering place for mercury elements are the roots and leaves ${ }^{33}$. Cyanide when exposed to light in an environment will turn into free cyanide which is very toxic and volatile.

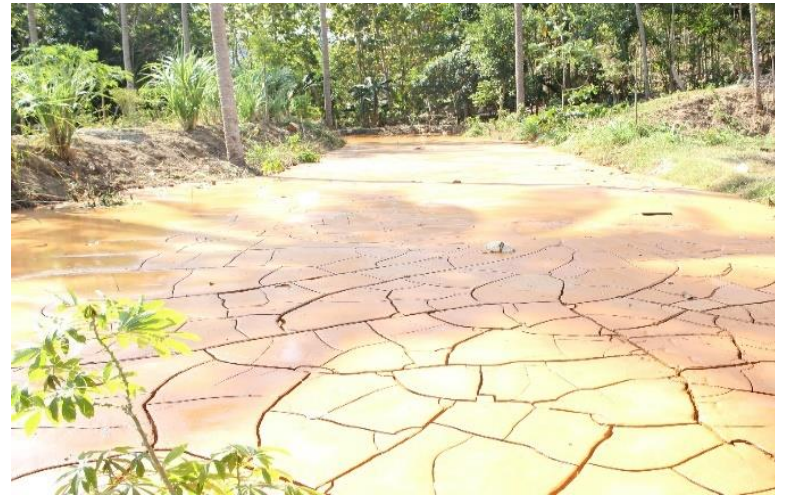

(a)

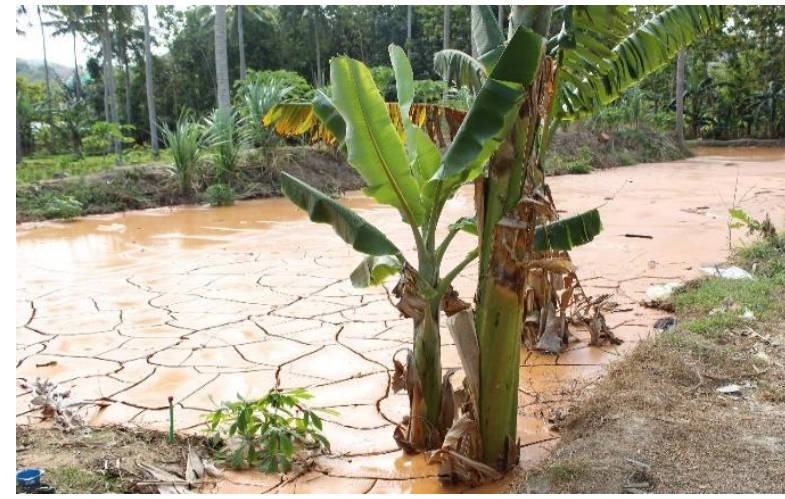

(b)

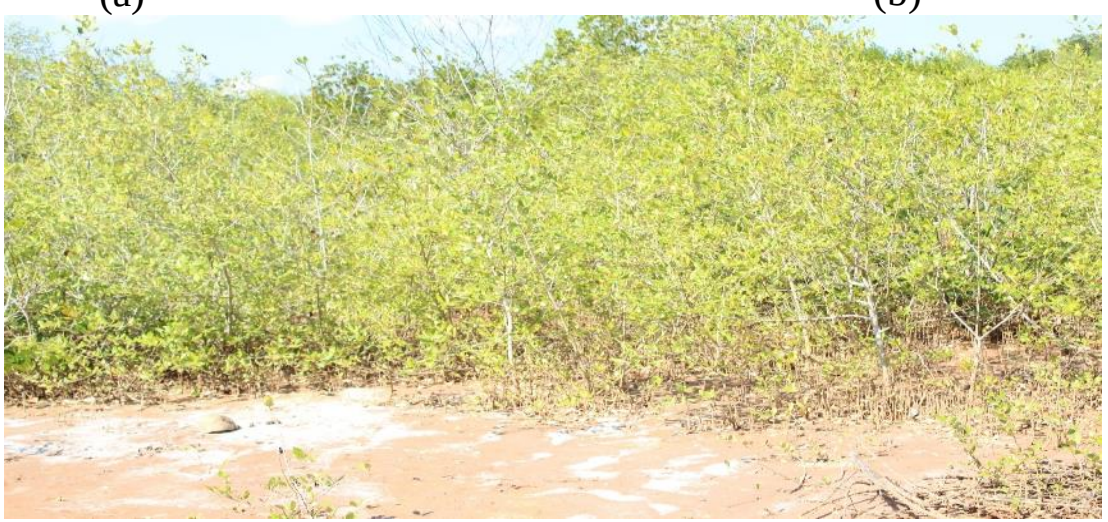

(c)

Fig 1. Soil conditions in January 2019 (a), Plants conditions in January 2019 (b), Tailings damage the mangrove ecosystem, January 2019 (c).

\section{Conclusion}

People's gold mining activities at Sekotong District of West Lombok, West Nusa Tenggara have a negative impact on the environment. The use of mercury (Hg) and cyanide $(\mathrm{CN})$ in the gold extraction process can cause pollution in soil and plants. The results showed 
the $\mathrm{Hg}$ content on the surface of the surface made it easy from $2.90-26.94 \mathrm{mg} / \mathrm{Kg}$, the $\mathrm{Hg}$ in the soil depth of $30 \mathrm{~cm}$ reached 3.48-53.86. HCN content in the soil surface is $63.93-104.08 \mathrm{mg} / \mathrm{Kg}$, HCN in the soil depth of $30 \mathrm{~cm}$ reaches $66.59-106.55 \mathrm{mg} / \mathrm{Kg}$. The content of mercury and cyanide in rice (Oryza sativa), cassava (Manihot esculenta), banana (Musa paradisiaca), chili (capsicum sp), turi (Sesbania grandiflora), mango (Mangifera indica), mangrove (Rhizophora apiculata), and grass (Eleusine indica). The Hg content in these plants ranges from 1.23-8.15 $\mathrm{mg} / \mathrm{Kg}, \mathrm{HCN}$ content ranges from 18.41 to 52.85 . Referring to the standards set by WHO and Republic of Indonesia Health Number 57 of 2016, the soil and plants have been polluted and have a negative impact on the making of other lives.

\section{References}

1. Suhartini \& Abubakar. Socio economic impacts and policy of artisanal small-scale gold mining in relation to sustainable agriculture a case study at Sekotong of West Lombok. J. Degrad. Min. Lands Manag. 4, 789-796 (2017).

2. Utomo, W. H., Retno Suntari, Arfarita, N., Suhartini \& Handayanto, E. Rehabilitation of artisanal small-scale gold mining land in West Lombok, Indonesia: 3. Exploration of indigenous plant species and the associated mycorrhiza for Phytomycore mediation of mercury contaminated soils. Am. J. Sustain. Agric. 8, 34-41 (2014).

3. Lamare, A. Top 10 gold producing countries in the world. Celebrity Net Worth https://www.celebritynetworth.com/articles/entertainment-articles/top-10-goldproducing-countries-world/ (2013).

4. Ismawati, Y. Empowering the urban poor to solve their sanitation problem. Water Pract. Technol. 5, wpt2010107 (2010).

5. Chamid, C., Renosori, P. \& Wulandari, P. T. Sosialisasi resiko paparan merkuri pada keseharan wanita di lingkungan kampus UNISBA. in Prosiding Seminar Nasional Penelitian dan Pengabdian pada Masyarakat 307-314 (Universitas Islam Bandung, 2012).

6. Sancayaningsih, R. P. et al. Studi ekologi dan kandungan merkuri pada pertambangan emas tradisional di Kecamatan Sekotong,Lombok Barat. (UGM, 2010).

7. Ulfa, A., Suarsini, E. \& Irawati, M. H. Pengembangan buku ajar mikrobiologi tentang bioreduksi merkuri bagi mahasiswa pendidikan biologi. J. Pendidik. Teor. Penelitian, dan Pengemb. 2, 42-49 (2017).

8. Krisnayanti, B. D. ASGM status in West Nusa Tenggara Province, Indonesia. J. Degrad. Min. Lands Manag. 5, 1077-1084 (2018).

9. World Health Organization. Guidelines for the safe use of wastewater, excreta and greywater in agriculture and aquaculture. (2006).

10. World Health Organization. Hydrogen cyanide and cyanides : human health aspects. Concise International Chemical Assessment Document 61 (World Health Organization, 2004).

11. Kementerian Kesehatan Republik Indonesia. Peraturan Menteri Kesehatan tentang Rencana Aksi Nasional Pengendalian Dampak Kesehatan Akibat Pajanan Merkuri Tahun 2016-2020. (Kementerian Kesehatan, 2016).

12. Hadi, A. Pengambilan Sampel Lingkungan. (Erlangga, 2015).

13. Hamzah, A. \& Priyadarshini, R. Identification of Wild grass as remediator plant on artisanal gold mine tailing. Plant Sci. Int. 1, 33-40 (2014). 
14. Jamil, N., Baqar, M. \& Shaikh, I. A. Assessment of mercury contamination in water and soil surrounding a chlor-alkali plant: a case study. J. Chem. Soc. Pakistan 37, 173-178 (2015).

15. Suhadi, Sueb \& Wedhanto, S. Pollution of Pb Metal on Soil at Burned Forest Areas at Baluran National Pollution of Pb Metal on Soil at Burned Forest Areas at Baluran National Park -East Java Indonesia . Int. Conf. Life Sci. Technol. 276, (2019).

16. Juliawan, N., Widhiyatna, D. \& Jatim, J. Pendataan penyebaran unsur merkuri pada wilayah pertambangan Cibaliung, Kabupaten Pandeglang, Provinsi Banten. http://psdg.bgl.esdm.go.id/index.php?option=com_content\&id=183 (2005).

17. Mirdat, M., Patadungan, Y. S. \& Isrun, I. Status logam berat merkuri (Hg) dalam tanah pada kawasan pengolahan tambang emas di kelurahan Poboya, kota Palu. AGROTEKBIS E-JURNAL ILMU Pertan. 1, 127-134 (2013).

18. Mi'u, Y. Analisis kandungan merkuri (Hg) pada tanah sawah di desa Taluduyunu kecamatan Buntulia kabupaten Pohuwato. (Universitas Negeri Gorontalo, 2013).

19. Raikwar, M. K., Kumar, P., Singh, M. \& Singh, A. Toxic effect of heavy metals in livestock health. Vet. Q. 1, 28-30 (2008).

20. Polii, B. J. \& Sonya, D. N. Pendugaan kandungan merkuri dan sianida di daerah aliran sungai (DAS) Buyat Minahasa. EKOTON 2, 31-37 (2002).

21. Mukhopadhyay, S. \& Maiti, S. K. Phytoremediation of metal mine waste. Appl. Ecol. Environ. Res. 8, 207-222 (2010).

22. Hidayati, N., Juhaeti, T. \& Syarif, F. Mercury and cyanide contaminations in gold mine environment and possible solution of cleaning up by using Phytoextraction. HAYATI J. Biosci. 16, 88-94 (2009).

23. Egekeze, J. O. \& Oehme, F. W. Cyanides and their toxicity : A literature review. Vet. Q. 2, 104-114 (2011).

24. Jaszczak, E., Polkowska, Ż., Narkowicz, S. \& Namieśnik, J. Cyanides in the environment — analysis-problems and challenges. Environ. Sci. Pollut. Res. 24, 15929-15948 (2017).

25. Saha, P., Mondal, A. \& Sarkar, S. Phytoremediation of cyanide containing steel industrial wastewater by Eichhornia crassipes. Int. J. Phytoremediation 20, 1205-1214 (2018).

26. Hamzah, A., Kusuma, Z., Utomo, W. H. \& Guritno, B. Siam weed ( Chromolaena odorata L .) for phytoremediation of artisanal gold mine tailings. J. Trop. Agric. 50, 8891 (2012).

27. Hidayati, N. \& Saefudin. Potensi hipertoleransi dan serapan logam beberapa jenis tumbuhan pada limbah pengolahan emas. Indones. J. Biol. 3, 351-359 (2005).

28. Ghosh, M. \& S. P. Singh. A review on phytoremediation of heavy metals and utilization of it’s by products. Asian J. Energy Environ. 6, 214-231 (2005).

29. Cho, U.-H. \& Park, J.-O. Mercury-induced oxidative stress in tomato seedlings. Plant Sci. 156, 1-9 (2000).

30. Patra, M. \& Sharma, A. Mercury toxicity in plants. Bot. Rev. 66, 379-422 (2000).

31. Abraham, K. \& Damodharam, T. Effect of the $\mathrm{HgCl} 2$ on germination and seedling growth of Arachies hypogiea L. Ann. Biol. Res. 3, 3297-3299 (2012). 
32. Patnaik, A. \& Mohanty, B. K. Toxic effect of mercury and cadmium on germination and seedling growth of Cajanus cajan L (Pigeon pea). Ann. Biol. Res. 4, 123-126 (2013).

33. Suhendrayatna, S., Ohki, A. \& Gultom, A. C. Mercury levels and distribution in organs of freshwater organisms from Krueng Sabe River Aceh Jaya, Indonesia. in 6th Annual International Workshop \& Expo on Sumatra Tsunami Disaster \& Recovery 2011 (Universitas Syiah Kuala, 2011).

\section{Author contributions}

All authors contributed to the study's conception and design. Material preparation, data collection and analysis were performed by All Author. The first draft of the manuscript was written by Third and Fourth author, all authors commented on previous versions of the manuscript. All authors read and approved the final manuscript. 